なる㴽か, 特別の差を認めなかったが, 全般的に外䂓性の 個人の不注意に上る学災が全疾患の90\%前後をしめ, そ の荻害発生は安全保安運動の推進により予放できること が認められた。九州・山口地区に和ける労災疾病発生率は 1 号学災 $(0.98 \%$ \% ， 3 号 $(0.50 \%) ， 2$ 号 $(0.44 \%$ \% ， 6 号롤 $(0.25 \%) ， 14 \sim 32$ 号各種”中毒群 $(0.11 \% 0), 38$ 号 $(0.08 \% 0) ， 5$ 号， 7 号 $(0.05 \% 0) ， 12$ 号 $(0.01 \%$ )であっ た。

以上，九州・山口地区に就学笔発生に関しては，山 口を含めた福阔，佐賀，長崎，熊本各県の北部ブロック 之, 大分, 宮崎, 庇児島の南部ブロックに拈いて, 前者 は学猋発生率も高率であり，その発生学炭疾病の内容も 多種多様であるのに比較して，後者は学多発生率も低率 であり，その発生労災疾病の内容は単純であることが観 察され，第 2 次産業と第 1 次産業の発澾の差に上り，烦 害の発生率内容が異なることが明らかに覞察できた。し かしその災害発生率は外傷性の疾病が主体をしめること より考光るとき，今後とも保安運動の推進が必要である ことを痛感した。

\section{9. 某機械工業における労災上の骨折}

$$
\text { 秋山舜一，福山裕三（不二越病院） }
$$

企業が掂大されるにつれて，外僬性の災憲は増加の途 をたどるが，その外㑺性災害の発生状沉の概峈を見よう とするとき，ある種の機械工業では骨折がその指標とな り得る。

即らこの種の工業で使われる機械及び材料はその災害 が甚しい時は骨折に至らしめる伦険性を充分に具倩して いるからである。

このような観点から私達は不二戎鋼材富山工場及びそ の下請会社に括ける昭和34年 1 月以後現在に至るまでの 労荻上の骨折の発生状況を統計的に解析したのでここ に報告する。要旨はつぎのとおりである。

1）この種の工業に括る骨折の 93\% \%でが指趾に 発生し，指趾ともに左右の差はなく，示指，中指，拇趾 に最も多く発生している。前二者はこれらの指が作業の 中心となること，後者は体の支点となることに関連があ ろら。

2）骨折の原因では材料の落下が多く，ついでプレス による压挫，砥石による切削の順となっている。

3) 骨折の発生時刻は作業終了面前即ち午前11時，午 後 3〜4 時に最も多く発生している。

4） 1 週の中では月，土矅に多く，肉体的疫学上りも 精神的要素に深い関係を有すると思われる。
5）季節的には入社時の 4〜5 月ごろと 10〜12月の寒 冷時に多く発生している。

6) 年齢別に見ると，15－20藏の未熟者群と40歳前後 の高命者群に多い。

7）経験年数別に見ると，5年内外のようやく機椷に

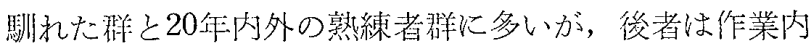
容の複雑さ（段取り）と高令による骨変化がその要因を なしているものと舁われる。

\section{0. 林業作業による災害の調疽研究}

柳沢文徳（東医菌大農研）

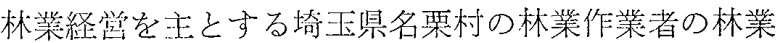
に関連して，発生した災害の淍查研究成績を報告する。

昭和31年度の同村の受診篗病洞查上り，国際㙏病分類 による 3 XVI 項の発生率は人口1,000に対しで 97.6で

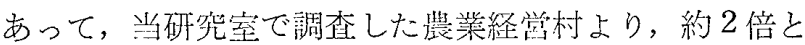
いら実態であることより，林業村では外傢がいかに多い かが判明した。

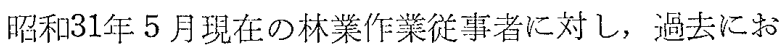
げる林紫災害の状海を検詩した。その災害の程度は約 1

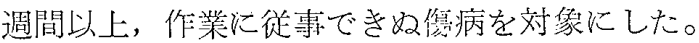

災害者は 117 名で，受傷回数は 148 回で 1 回，82.9\% 2 回 10.3\%，3回 $5.1 \%$ で最高が 5 回であった。

年齢別で清青壮年厤に多く認められた。傷病区分では 打撲傷 $30.4 \%$ ，骨折 $40.5 \%$ ，切傷 $17.6 \%$ ，刺傷 $2.7 \%$ 挫傢 $6.1 \%$ ，その他 $2.7 \%$ であった。骨折が多いのに 注目さ机る。ぬた長期にわたる後遗症が認わら机たもの は約 50\%であった。

作業内容との関係は村木運搬が 64 回，つぎが伐木で 16回，枝打13回となっており，運搬でも“そり引き”の 場合が王倒的に多いのは注目される。

その弫か集萝した資料より解析しえた成績を二，三の ベるが，本調查によって，林業作㮍による多害は大さな 賃病が多いことにより，作盖内容の改善の必要性がつよ く認められた。

\section{1. 救急用人工呼吸装置の試作について}

梨本一郎，山口 裕（東医崡大衛生）

座策部門に招ける救急用人工呼吸装犆は多種にわたっ ているが，機能的には满足すべきのがきわめて少な い。演者らは，従来指摘されている不備な点を改良して 新らしい機情の人工呼吸装犆を試作し，実験的仔成績 を得た。 